\title{
EFFECT OF DIFFERENT NITROGEN AND PHOSPHORUS SOURCES ON WHEAT YIELD, ITS COMPONENTS AND CHEMICAL CHARACTERISTICS UNDER DIFFERENT SOIL CONDITIONS
}

\author{
EI-Bialy, U. S. and E. A. M. Osman
}

Soils, Water and Environ. Res. Inst., Agric. Res. Center (ARC), Giza, Egypt

\begin{abstract}
A field experiment was conducted in two locations at Bahtim Agricultural Research Station, Kaluobia Governorate during the winter growing season, $2006 / 2007$ to study the effect of different phosphorus sources, i.e., single superphosphate \& triple superphosphate and different nitrogen fertilizers sources (ammonium sulphate, calcium nitrate and urea) on grain, straw and biological yields as well as nutrients uptake of wheat plant variety (Giza 168).

Results can be summarized as follows:

Generally, the grain, straw and biological yield of wheat plants grown on nonsaline soil was twice or more than that resulted from saline soil.

In non-saline soil, there was a significant higher for single superphosphate on biological yield, while triple superphosphate achieved high values of $P$ and $M n$ uptake in biological yield. Meanwhile, no significant differences were observed between sources of phosphorus fertilizer on the other nutrients uptake in biological yield. The source of phosphorus fertilizer had no significant effect on grain and straw yields of wheat plants as well as nitrogen uptake \& protein \% in grain, also, N, P and $\mathrm{K}$ uptake in straw yield. While, there was a significant increase due to the application of triple superphosphate on $\mathrm{P}, \mathrm{K}, \mathrm{Fe}, \mathrm{Zn}$ and $\mathrm{Mn}$ in grain yield as well as $\mathrm{Mn}$ uptake in straw yield. Regarding the interaction effect of phosphorus and nitrogen fertilizer sources, there was no clear trend due to most cases of nutrients uptake by grain and straw yield.

In saline soil, triple superphosphate gave the highest significant values in all parameters under study compared to single superphosphate. Concerning of nitrogen fertilizer sources, ammonium sulphate gave the highest significant values in most parameters under study compared to other nitrogen sources. Regarding the interaction effect between phosphorus and nitrogen fertilizer sources, triple superphosphate with ammonium sulphate gave the highest values for the most parameters compared to other treatments.
\end{abstract}

Keywords: wheat; yield component; $P$ and N sources; P, N and Salinity interactions.

\section{INTRODUCTION}

Wheat is one of the most important cereal crops in Egypt, which its demand is increasing in all countries for animal and human consumption. Therefore, a great attention should be given to increase its productivity and improve its quality. Considerable researches have been reported on the salt tolerance of wheat cultivars over the past years (Epstein, 1985, François et al., 1986, Epstein and Rains, 1987).The growing increase of salt-affected soils in Egypt needs substantial investigations to identify the optimal fertilizer programs that could be applied to minimize the adverse effect of salinity on 
crop yields. In spite of the fact that $P$ utilization by the growing plants in soils is usually limited (Jungk et al., 1993) and did not exceed 10\% (Schenk and Barber, 1979), increasing $P$ fertilization has been intensively practiced to stimulate yield potential and to alleviate growth inhibition under salt-stressed condition. Soil salinzation is one of the most common land degradation processes in arid and semi-arid regions, where precipitation exceeds over evaporation. Under such climatic conditions, soluble salt are accumulated in the soil, influencing soil properties and environment with ultimate decline in soil productivity (Abdelfattah et al., 2009).

Reported data on the salinity-phosphorus interaction have shown that $P$ fertilization in salt- affected soils may be beneficial in reducing the depressing effects on yield as long as the salinity level is low or in medium range (Bermstein et al., 1974).

Salt stress is an important constraint that affects crop production in arid and semiarid regions. However, improved nitrogen $(\mathrm{N})$ and phosphorus $(\mathrm{P})$ nutrition may enhance the performance of salt stressed crop plants (Soliman and Doss, 1992). Soliman et al., (2004) revealed that salt stress progressively inhibited wheat plant growth in terms of straw and grain yields. At low salinity $\left(4.0 \mathrm{dS} \mathrm{m}^{-1}\right)$, straw and grain yields were reduced by $10 \%$ and $14 \%$, respectively, as compared to the control treatment. Higher salinity levels led to decrease straw yield by 40 and $60 \%$ and grain yield by 40 and $52 \%$ at 8.2 and $12.5 \mathrm{dSm}^{-1}$, respectively.

The form of $\mathrm{N}$ supply is known to influence the availability of other plant nutrients, notably phosphorus, through its effect on soil $\mathrm{pH}$ in the rhizosphere. In general, $\mathrm{pH}$ decreases when ammonium was used as $\mathrm{N}$ fertilizer and $\mathrm{pH}$ increases with the application of nitrate nitrogen (Youssef, and Chino, 1988). Gahoonia et al. (1992) also showed that the soil pH of the root surface of ryegrass decreased and that Ca-P of luvisol was dissolved when $\mathrm{N}$ was applied as $\mathrm{NH}_{4}$. Plants may change soil $\mathrm{pH}$ in the vicinity of their roots, Zhang et al. (2004) and thus affect the availability of phosphate. In addition, Irshad et al. (2002) found that the Plant growth and nutrient uptake were influenced by both salinity and source of $\mathrm{N}$. As expected, increasing salinity decreased dry matter production of shoot and root, whereas $\mathrm{N}$ application increased plant growth across all levels of salinity. The total dry biomass (shoot and root) of wheat was significantly higher in combined $\mathrm{N}$ treatments than in single sources. Irrespective of $\mathrm{N}$ forms most of the nutrient concentrations in the shoot was increased with increasing level of salinity. Among the fertilizers the concentration, cation was higher in nitrate-treated plants than in other forms of $\mathrm{N}$. Ammonium-N and urea-N tended to inhibit the uptake of cations compared to nitrate-N under saline conditions. The trend for $\mathrm{P}$ and $\mathrm{Cl}$ concentrations was almost opposite to that of cations concentration in the shoot.

The aim of this work is to study the effect of different phosphorus and nitrogen sources fertilizers on grain, straw and biological yields as well as nutrients uptake of wheat plant under different soil conditions. 


\section{MATERIALS AND METHODS}

The current work was carried out at Bahtim Agricultural Research Station during the winter seasons of 2006/2007 to study the effect of phosphorus and nitrogen fertilizers sources on on grain and straw yields as well as nutrients uptake of wheat plant variety (Giza 168),. The site for laying out the trials was chosen at two locations having different soil salinity level.

Soil of the experimental field was sampled to certain the soil particle size distribution and chemical analysis before planting according to the standard methods of Ryan et al. (1996). The results of these analyses are presented in Table (1, a and 1, b)

Table $(1$, a):Some physical and chemical properties of the studied soils

\begin{tabular}{|c|c|c|c|c|c|c|c|c|c|}
\hline \multirow[t]{2}{*}{ Soils } & \multirow{2}{*}{$\mathrm{pH}$} & \multirow{2}{*}{$\begin{array}{l}\text { EC } \\
\text { dSm }\end{array}$} & OM & $\mathrm{CaCO}_{3}$ & S.P & Sand & Silt & Clay & \multirow{2}{*}{$\begin{array}{c}\text { Soil } \\
\text { texture }\end{array}$} \\
\hline & & & \multicolumn{6}{|c|}{$\%$} & \\
\hline $1^{\text {st }}$ location & 7.6 & 1.8 & 1.4 & 2.6 & 64 & 15 & 33 & 52 & Clay \\
\hline $2^{\frac{\text { nd }}{2}}$ location & 8.2 & 8.5 & 1.1 & 3.4 & 59 & 14 & 28 & 58 & Clay \\
\hline
\end{tabular}

Table $(1, b)$ : Cation and anion as well as nutrient concentration in a paste extract of the studied soil samples

\begin{tabular}{|c|c|c|c|c|c|c|c|c|c|c|c|c|c|c|}
\hline \multirow{2}{*}{ Soils } & $\mathbf{C a}^{++}$ & $\mathbf{M g}^{++}$ & $\mathrm{Na}^{+}$ & $\mathrm{K}^{+}$ & $\mathrm{CO}_{3}^{--}$ & $\mathrm{HCO}_{3}^{-}$ & $\mathrm{Cl}^{-}$ & $\mathrm{SO}_{4}^{--}$ & $\mathbf{N}$ & $\mathbf{P}$ & $\mathrm{K}$ & $\mathrm{Fe}$ & Mn & $\mathrm{Zn}$ \\
\hline & \multicolumn{8}{|c|}{$\mathrm{Mmol} / \mathrm{I}$} & \multicolumn{6}{|c|}{ Available (ppm) } \\
\hline $1_{-}^{\text {st }}$ location & 7.9 & 6.1 & 7.5 & 1.3 & 0.0 & 2.6 & 6.1 & 14.1 & 37.4 & 7.4 & 345 & 9 & 2.2 & 3.1 \\
\hline $2^{\frac{\text { nd }}{n}}$ location & 9.3 & 4.6 & 59.2 & 0.8 & 0.0 & 3.2 & 3.2 & 67.5 & 38.7 & 6.2 & 360 & 8 & 2.4 & 3.8 \\
\hline
\end{tabular}

Wheat grains (Giza 168), were planted at the rate of $70 \mathrm{~kg} / \mathrm{fed}$. On20 November, 2006.

Experiment in both locations was arranged in a split plot design with three replications of $10.5 \mathrm{~m}^{2}$ (1/400 fed.) in which the main treatments were devoted for source of phosphorus fertilizer, while the sub-ones included source of nitrogen fertilizer. Such treatments were as follows:-

1- Phosphorus fertilizer sources.

- Triple superphosphate (TSP).

- Single superphosphate (SSP).

2- Nitrogen fertilizer sources:

- Ammonium Sulphate $(20.6 \% \mathrm{~N})$.

- Calcium Nitrate $(33.5 \% \mathrm{~N})$.

- Urea $(46.5 \% \mathrm{~N})$.

The fertilizer was applied in three equal portions, i.e., before planting, first and second irrigation, 21 and 43 days from planting, respectively.

A basal application of $48 \mathrm{~kg} \mathrm{~K} \mathrm{O} / \mathrm{fed}$. as potassium sulphate $(48 \%$ $\mathrm{K}_{2} \mathrm{O}$ ) was applied to all experimental plots after 18 and 31 days of planting. All cultural practices were carried out according to usual methods being adopted for such crop. The crop was harvested at full maturity on the $15^{\text {th }}$ of May, 2007. Grain, straw and biological yields were recorded. Random samples of grain and straw representing each replicate of all treatments were collected, oven dried, digested and assigned for analyzing $\mathrm{N}, \mathrm{P}, \mathrm{K}, \mathrm{Fe}, \mathrm{Mn}$, and $\mathrm{Zn}$. 
Nitrogen was determined using modified Kjeldahl method, the grains protein percentage was calculated by multiplying $N \% X 5.75$. Phosphorous was determined colorimetrically using ammonium molybdate and ammonium metavanadate according to the procedure outlined by Ryan et al. (1996).Potassium was determined using the flame spectrophotometry method (Black, 1982).Micronutrients ( $\mathrm{Fe}, \mathrm{Mn}$, and $\mathrm{Zn}$ ) were determined using atomic spectrophotometer absorption, Perkin-Elmer 372 according to the procedure outlined by Ryan et al. (1996).

Results were statistically analyzed using M-stat computer package to calculate F ratio according to Snedecor and Cochran (1980). Least significant differences method (L.S.D) was used to differentiate means at the 0.05 level (Waller and Duncan, 1969).

\section{RESULTS AND DISCUSSION}

\section{Yield}

The effect of phosphorus and nitrogen fertilizer sources and their interaction on grain, straw and biological yield of wheat plant grown on nonsaline soil are shown in Tables (2, 4 and 6), while such effect for saline soil is presented in Tables ( 3,5 and 7$)$. It is interesting to note that grain, straw and biological yield of wheat plants grown on non-saline soil was twice or more than that resulted from saline soil. This result indicates that wheat plants is severe strongly affected under saline soil as a result of the harmful effect of salinity hazard. Results also revealed that the source of phosphorus fertilizer had no significant effect on wheat grain and straw yields for grown on nonsaline soil, while biological yield was significantly affected by such source. This result agree with those obtained by El-Etreiby (2002) and Aboushal and EL-Ashtar (2006), who concluded that the reduction of wheat grain yield resulted from increasing salinity was attributed mainly to a reduction in number of spikes/pot and 100-grain weight. On the contrary, grain, straw and biological yield were significantly affected by phosphorus fertilizer source where such yields were significantly higher by using triple superphosphate than those resulted from the addition of single superphosphate. The insignificant influence of $P$ fertilizer sources on grain and straw yield of wheat plant grown on non-saline soil could be elucidated to the suitable growth conditions of the non-saline soil, which create good physical and chemical properties of soil and that reflected on nearly equal grain and straw yield of wheat plant.

Concerning the effect of the source of nitrogen fertilizer, various trends of yield, i. e., grain, straw and biological one of wheat plants grown on both soils were noticed. Results indicated that grain yield of wheat plants grown on both soils was significantly affected by nitrogen source, where ammonium sulphate had significantly surpassed the others. This result may be due to the good buffer effect of ammonium sulphate which is considered as fertilizer having acidic physiological effect especially in saline soil, which could be gone towards alkalinity state. Similar results were obtained by Taalab and Badr (2007) who concluded that rhizosphere soils increase with 
the addition of $\left(\mathrm{NH}_{4}\right)_{2} \mathrm{SO}_{4}$ than with $\mathrm{Ca}\left(\mathrm{NO}_{3}\right)_{2}$ at same rates of application. On the other hand, the effect of nitrogen source took different trend in both soil under study, whereas such effect was insignificant in saline soil, while it is opposite in non-saline soil, where it was significant.

Table (2): Effect of phosphorus and nitrogen fertilizer sources on grain yield, macro and micro nutrients uptake as well as protein percentage on wheat plant grown in non saline soil

\begin{tabular}{|c|c|c|c|c|c|c|c|c|}
\hline \multirow[t]{2}{*}{ Treatments } & $\begin{array}{l}\text { Grain } \\
\text { yield }\end{array}$ & $\mathbf{N}$ & $P$ & $\mathbf{k}$ & $\mathrm{Fe}$ & Zn & Mn & \multirow{2}{*}{\begin{tabular}{|c|} 
Protein \\
$\%$ \\
\end{tabular}} \\
\hline & Ton/ fed & \multicolumn{3}{|c|}{ Uptake (Kg/ fed) } & \multicolumn{3}{|c|}{ Uptake (g/ fed) } & \\
\hline $\begin{array}{ll}\text { Triple superphosphate } \\
\text { (TSP) }\end{array}$ & 2811 & 53.47 & $7.83^{* \star}$ & $8.22^{* *}$ & $831.77^{* *}$ & $321.69^{* *}$ & $99.99 *$ & 10.91 \\
\hline $\begin{array}{ll}\text { single } & \text { superphosphate } \\
\text { (SSP) }\end{array}$ & 2875 & 54.15 & 6.91 & 6.94 & 806.71 & 272.61 & 87.36 & 10.90 \\
\hline LSD at $5 \%$ & NS & NS & & & & & & NS \\
\hline Ammonium Salphate & 2937 & 59.60 & 7.86 & 6.56 & 881.3 & 293.5 & 100.3 & 11.68 \\
\hline Calcium Nitrate & 2805 & 52.67 & 7.12 & 8.49 & 910.9 & 298.9 & 91.09 & 10.80 \\
\hline Urea & 2760 & 49.15 & 7.14 & 7.68 & 665.5 & 299.1 & 89.63 & 10.24 \\
\hline LSD at $5 \%$ & 147.4 & 2.91 & 0.50 & 0.56 & 45.13 & NS & NS & 0.61 \\
\hline $\begin{array}{|ll|}\text { (TSP) Ammonium } \\
\text { Salphate }\end{array}$ & 2927 & 61.65 & 8.25 & 6.19 & 751.1 & 331.8 & 107.3 & 12.12 \\
\hline (TSP)+ Calcium Nitrate & 2775 & 52.89 & 7.58 & 10.68 & 971.1 & 333.0 & 97.11 & 10.96 \\
\hline$(\mathrm{TSP})+$ Urea & 2730 & 45.87 & 7.67 & 7.78 & 773.0 & 300.3 & 95.56 & 9.66 \\
\hline $\begin{array}{l}\text { (SSP) }+ \text { Ammonium } \\
\text { Salphate }\end{array}$ & 2946 & 57.55 & 7.46 & 6.93 & 1012.0 & 255.2 & 93.33 & 11.23 \\
\hline (SSP) Calcium Nitrate & 2835 & 52.45 & 6.66 & 6.30 & 850.6 & 264.8 & 85.06 & 10.64 \\
\hline (SSP) + Urea & 2790 & 52.44 & 6.60 & 7.57 & 558.0 & 297.8 & 83.70 & 10.81 \\
\hline LSD at $5 \%$ & 208.5 & 4.12 & 0.71 & 0.79 & 76.55 & 50.82 & 18.81 & 0.87 \\
\hline
\end{tabular}

Table (3): Effect of phosphorus and nitrogen fertilizers sources on grain yield, macro and micro nutrients uptake as well as protein percentage of wheat plant grown in saline soil

\begin{tabular}{|c|c|c|c|c|c|c|c|c|}
\hline \multirow[t]{2}{*}{ Treatments } & $\begin{array}{l}\text { Grain } \\
\text { yield }\end{array}$ & $\mathbf{N}$ & $\mathbf{P}$ & $\mathbf{k}$ & $\mathrm{Fe}$ & Zn & Mn & \multirow{2}{*}{$\begin{array}{c}\text { Protein } \\
\% \\
\end{array}$} \\
\hline & Ton/fed & \multicolumn{3}{|c|}{ Uptake (Kg/ fed) } & \multicolumn{3}{|c|}{ Uptake (g/ fed) } & \\
\hline $\begin{array}{|lr|}\text { (TSP) } & \text { Triple } \\
\text { superphosphate } & \\
\end{array}$ & $1.363^{*}$ & $26.64^{*}$ & $3.82^{*}$ & $4.69^{\star}$ & $357.26^{*}$ & $167.41^{*}$ & $54.51^{*}$ & 11.19 \\
\hline $\begin{array}{l}\text { (SSP)single } \\
\text { superphosphate }\end{array}$ & 1.061 & 20.27 & 2.57 & 3.66 & 281.99 & 116.15 & 35.50 & 10.98 \\
\hline LSD at $5 \%$ & & & & & & & & NS \\
\hline Ammonium Salphate & 1.389 & 28.03 & 3.76 & 4.67 & 348.6 & 162.9 & 53.66 & 11.56 \\
\hline Calcium Nitrate & 1.132 & 21.82 & 2.93 & 4.08 & 275.9 & 121.1 & 41.17 & 11.13 \\
\hline Urea & 1.116 & 20.51 & 2.90 & 3.78 & 334.4 & 141.4 & 40.19 & 10.57 \\
\hline LSD at $5 \%$ & 0.125 & 1.91 & 0.51 & 0.41 & 16.81 & 18.01 & 7.59 & 0.60 \\
\hline $\begin{array}{l}\text { (TSP) } \\
\text { Salphate }\end{array}$ & 1.648 & 33.93 & 4.65 & 5.60 & 471.3 & 197.7 & 65.91 & 11.84 \\
\hline$($ TSP)+ Calcium Nitrate & 1.277 & \begin{tabular}{|l|}
24.27 \\
\end{tabular} & 3.53 & 4.47 & 5.3 & 153.2 & 51.07 & 10.98 \\
\hline (TSP) + Urea & 1.164 & 21.71 & 3.27 & 4.00 & 345.1 & 151.3 & 46.56 & 10.74 \\
\hline $\begin{array}{l}\text { (SSP) } \\
\text { Salphate }\end{array}$ & 1.129 & 22.14 & 2.86 & 3.74 & 225.9 & 128.0 & 41.41 & 11.27 \\
\hline (SSP) Calcium Nitrate & 0.988 & 19.37 & 2.32 & 3.69 & 296.4 & 88.92 & 31.28 & 11.27 \\
\hline (SSP) + Urea & $1067 \mathrm{C}$ & 19.31 & 2.52 & 3.56 & 323.7 & 131.6 & 33.82 & 10.41 \\
\hline LSD at $5 \%$ & 0.176 & 2.70 & 0.72 & 0.58 & 23.77 & 25.47 & 10.74 & 0.85 \\
\hline
\end{tabular}


Apparently, grain and straw yields of wheat plants grown on nonsaline soil were significantly increased due to the use of ammonium sulphate fertilizer compared to those treated with the other fertilizers (Calcium nitrate or Urea). In this connection, El- Sherief et al. (2008) found that, the maximum maize yield has been obtained with ammonium sulphate and the lowest one was recorded with ammonium nitrate and urea.

Regarding the interaction effect between the studied factors, results revealed that grain, straw and biological yields were significantly affected by interacted treatments. Wheat plants grown on non-saline or saline soil and fertilized with triple superphosphate combined with ammonium sulphate yielded significantly higher grain, straw and biological yields. This result could be attributed to the individual effect mentioned previously, of the factors under study. In this respect, Fawzy et al. (1983) noted that fertilization improves soil productivity but under saline conditions, it does not directly seem to help in increasing crop production. But indirectly it decreases the harmful effect of salinity by providing nutrients to the plants for their functions.

\section{Nutrients uptake}

Macro and micro nutrients uptake by wheat plants grown on nonsaline and/ or saline soils as affected by different phosphorus and nitrogen fertilizer sources and their interaction are presented in Tables (2, 3, 4, 5,6 and 7) . Regarding nutrients uptake by grain, data showed that there was a positive significant effect of phosphorus fertilizer sources on macro and micro- nutrients uptake under study in both saline and non-saline soils except for nitrogen uptake in non-saline soil. Moreover, the triple superphosphate, mostly, resulted in higher values of macro and micro-nutrients uptake by grains compared to those produced by single superphosphate. From the logic point of view, the state of nutrients uptake by grains was better and higher in non-saline soil compared to saline one. In this respect, El- Dewiny et al. (2005) found that the single superphosphate addition gave the lowest value of macronutrients uptake at different parts of sorghum plants compared with other treatments. It was noticed that the addition of TSP enhanced the macronutrients uptake through improving the nutrient supply.

As for nutrients uptake in grains due to different nitrogen fertilizer sources, results indicated that there was a positive significant effect between the treatments where ammonium sulphate was the best source in both non saline and saline soils. The exception may be noticed here that $\mathrm{Zn}$ and $\mathrm{Mn}$ uptake was insignificant in non-saline soil. Also, the nutrient uptake condition in non-saline soil was better than that of saline one. Similar results were obtained by Taalab and Badr (2007).

With regard to the interaction between different phosphorus and nitrogen fertilizer sources on nutrients uptake in grains, it is strongly concluded that the combined treatment of both TSP and ammonium sulphate recorded the best significant response compared to the other reacted treatments. This effect was more pronounced in case of saline soils. This may be due to the physiological acidic effect of both TSP and ammonium sulphate fertilizers, which might create better condition for wheat plants to absorb nutrients in saline soils. 
Tables (4 \& 5) show the main effect of phosphorus fertilizer sources on macro and micro-nutrients uptake in straw of wheat plants grown on nonsaline and saline soils. There was insignificant effect of both TSP and SSP on $\mathrm{N}, \mathrm{P}$ and $\mathrm{K}$ uptake in non-saline soils, but the positive significant trend was denied for micronutrients, where SSP has significant and higher values of $\mathrm{Fe}$ and $\mathrm{Zn}$ uptake, while TSS had the opposite trend for Mn uptake.

Concerning the main effect of different nitrogen fertilizer sources, as general, i.e., ammonium sulphate was superior to calcium nitrate and urea as for macro and micronutrients uptake with clear significant difference in nonsaline soils. The exception was shown for Fe uptake in straw where calcium nitrate and urea was similar with significant and higher difference compared to ammonium sulphate (Table 4). However, ammonium sulphate achieved the same trend, to some extent, in saline soils for N, P, Fe and Mn uptake in wheat straw. There was insignificant difference between nitrogen fertilizer sources under study on $\mathrm{K}$ and $\mathrm{Zn}$ uptake (Table, 5). Similar results were obtained by Zhang et al. (2004) and Irshad et al. (2002)

The interaction between $\mathrm{p}$ and $\mathrm{N}$ fertilizer sources on nutrients uptake in straw had different effects in case of non-saline soils compared to saline one. In non-saline soils, the combined treatment of TSS and ammonium sulphate recorded the best significant values regarding $\mathrm{N}, \mathrm{P}$, and Mn uptake. Meanwhile, the treatment of TSP+ urea achieved the highest and significant value for $\mathrm{K}$ uptake. In addition, the combined treatment of SSP+ ammonium sulphate had recorded the highest and significant values for $\mathrm{Fe}$ and $\mathrm{Zn}$ uptake (Table 4). The latter result may be explained as SSP contains such contaminated amounts of $\mathrm{Fe}$ and $\mathrm{Zn}$ beside the conditioning effect of ammonium sulphate. Similar results were obtained by Mitchell (1964) reported that SSP could contain as high as $100 \mathrm{mg} \mathrm{Zn}, 100 \mathrm{mg} \mathrm{Cu}$ and 5000 $\mathrm{Mn}$ (along with some others) per one $\mathrm{kg}$ of fertilizer material. In saline soil, the combination between TSS and ammonium sulphate caused significantly the highest values of all macro and micronutrients absorbed by straw (Table 5).

Data of macro and micro-nutrients uptake in biological yield of wheat plant grown on non-saline and / or saline soil are presented in Tables (6\& 8 ). The main treatments of P- fertilizer sources affected insignificantly $\mathrm{N}, \mathrm{K}, \mathrm{Fe}$ and $\mathrm{Zn}$ uptake. Meanwhile, $\mathrm{K}$ and $\mathrm{Mn}$ uptake in biological yield responded significantly in positive trend as a result of such main treatments in non-saline soil (Table, 6). In saline soil, it is clear that the main effect of P-fertilizer sources had also significant effect on all nutrients uptake in biological yield similar to that occurred in grain and straw yields emphasizing the priority of TSP than SSP (Table, 7). In this respect Taalab and Badr (2007) found that the dry matter yield of sorghum plants received $\left(\mathrm{NH}_{4}\right)_{2} \mathrm{SO}_{4}$ and compacted rock phosphate was appreciably higher than plants received the rock phosphate along with $\mathrm{NO}_{3}$ at both rates of application. Increasing $\mathrm{P}: \mathrm{N}$ ratio significantly increased dry matter production due to $\mathrm{NH}_{4}$ nutrition but not with $\mathrm{NO}_{3}$ nutrition

The main effect of nitrogen fertilizer sources on nutrients uptake in biological yield had the same trend in both non-saline and saline soils where all nutrients uptake responded significantly in a positive trend as a result of 
such nitrogen sources in exception of $\mathrm{K}$ uptake. Moreover, ammonium sulphate was the best fertilizer source.

Data of the interaction between phosphorus and nitrogen fertilizer sources treatments showed that also the significance was clear for all nutrients uptake in wheat biological yield grown on both non-saline and saline soils. Triple superphosphate added with ammonium sulphate recorded generally the best results of nutrients uptake. Similar finding was obtained by Taalab and Badr (2007)

Table (4): Effect of phosphorus and nitrogen fertilizer sources on straw yield, macro and micro nutrients uptake as well as protein percentage of wheat plant grown in non saline soil

\begin{tabular}{|c|c|c|c|c|c|c|c|}
\hline \multirow[b]{2}{*}{ Treatments } & \multirow{2}{*}{\begin{tabular}{|c|} 
Straw yield \\
Ton/ fed \\
\end{tabular}} & $\mathbf{N}$ & $\mathbf{P}$ & $\mathbf{k}$ & $\mathrm{Fe}$ & Zn & Mn \\
\hline & & \multicolumn{3}{|c|}{ Uptake (Kg/ fed) } & \multicolumn{3}{|c|}{ Uptake (g/ fed) } \\
\hline (TSP) Triple superphosphate & 5.583 & 57.65 & 3.48 & 175.37 & 2253.7 & 478.86 & $207.76^{\star}$ \\
\hline (SSP)single superphosphate & 5.626 & 58.93 & 3.18 & 174.86 & 2462.2* & $581.71^{\star}$ & 165.95 \\
\hline LSD at $5 \%$ & NS & NS & NS & NS & & & \\
\hline Ammonium Salphate & 5.845 & 65.87 & 3.49 & 161.9 & 2705 & 583.9 & 214.5 \\
\hline Calcium Nitrate & 5.432 & 53.99 & 3.14 & 181.5 & 2164 & 524.2 & 184.4 \\
\hline Urea & 5.537 & 55.02 & 3.34 & 181.9 & 2205 & 482.8 & 161.6 \\
\hline LSD at $5 \%$ & 0.231 & 9.78 & 0.34 & 9.37 & 103.8 & 73.45 & 23.51 \\
\hline (TSP) Ammonium Salphate & & 66.13 & 3.65 & 163.6 & 2479 & 511.6 & 245.8 \\
\hline (TSP)+ Calcium Nitrate & 5.213 & 49.96 & 3.11 & 172.9 & 2067 & 521.3 & 208.5 \\
\hline (TSP) + Urea & 5.632 & 56.87 & 3.68 & 189.7 & 2215 & 403.6 & 169.0 \\
\hline (SSP) + Ammonium Sal & 5.786 & 65.61 & 3.34 & 160.3 & 2932 & 656.1 & 183.2 \\
\hline (SSP) Calcium Nitrate & 5.651 & 58.01 & 3.19 & 190.2 & 2261 & 527.1 & 160.3 \\
\hline (SSP) + Urea & 5.442 & 53.16 & 3.01 & 174.1 & 2195 & 562.0 & 154.3 \\
\hline LSD at $5 \%$ & 0.326 & 13.83 & 0.45 & 13.26 & 146.8 & 103.9 & 33.24 \\
\hline
\end{tabular}

Table (5): Effect of phosphorus and nitrogen fertilizer sources on straw yield, macro and micro nutrients uptake as well as protein percentage of wheat plant grown in saline soil

\begin{tabular}{|c|c|c|c|c|c|c|c|}
\hline \multirow[b]{2}{*}{ Treatments } & \multirow{2}{*}{\begin{tabular}{|c|} 
Straw yield \\
Ton/ fed \\
\end{tabular}} & $\mathbf{N}$ & $\mathbf{P}$ & $\mathbf{k}$ & $\mathrm{Fe}$ & Zn & Mn \\
\hline & & \multicolumn{3}{|c|}{ Uptake (Kg/ fed) } & \multicolumn{3}{|c|}{ Uptake (g/ fed) } \\
\hline (TSP) Triple superphosphate & $3.319^{\star}$ & $36.28^{*}$ & $1.47^{*}$ & $25.17^{*}$ & $2065^{\star}$ & $337.4^{*}$ & $149.69^{\star}$ \\
\hline (SSP)single superphosphate & 2.354 & 24.58 & 0.96 & 18.11 & 1348 & 274.7 & 102.73 \\
\hline \multicolumn{8}{|l|}{ LSD at $5 \%$} \\
\hline Ammonium Salphate & 3.182 & 33.81 & 1.46 & 21.27 & 2017 & 352.7 & 154.4 \\
\hline Calcium Nitrate & 2.627 & 25.67 & 1.03 & 22.57 & 1661 & 295.0 & 109.5 \\
\hline Urea & 2.701 & 31.80 & 1.15 & 21.08 & 1441 & 270.5 & 114.7 \\
\hline LSD at $5 \%$ & NS & 6.84 & 0.38 & NS & 532 & NS & 31.28 \\
\hline (TSP) Ammonium Salphate & 3.557 & 39.84 & 1.69 & 27.00 & 2302 & 368.6 & 177.9 \\
\hline (TSP)+ Calcium Nitrate & 3.383 & 33.15 & 1.45 & 27.18 & 2224 & 372.2 & 140.8 \\
\hline$($ TSP) + Urea & 3.016 & 35.83 & 1.27 & 21.32 & 1668 & 271.5 & 130.4 \\
\hline (SSP) + Ammonium Salphate & 2.807 & 27.79 & 1.23 & 15.53 & 1731 & 336.8 & 131.0 \\
\hline (SSP) Calcium Nitrate & 1.871 & 18.19 & 0.61 & 17.95 & 1098 & 217.8 & 78.17 \\
\hline (SSP) + Urea & 2.385 & 27.76 & 1.04 & 20.84 & 1214 & 269.6 & 98.99 \\
\hline LSD at $5 \%$ & 1.067 & 9.68 & 0.53 & 9.48 & 752.4 & 118.3 & 44.23 \\
\hline
\end{tabular}


Table (6): Effect of phosphorus and nitrogen fertilizer sources on biological yield, macro and micro nutrients uptake of wheat plant grown in non saline soil

\begin{tabular}{|l|c|c|c|c|c|c|c|}
\hline \multirow{2}{*}{ Treatments } & $\begin{array}{c}\text { biological } \\
\text { yield }\end{array}$ & $\mathbf{N}$ & $\mathbf{P}$ & $\mathbf{k}$ & $\mathrm{Fe}$ & $\mathrm{Zn}$ & $\mathrm{Mn}$ \\
\cline { 2 - 9 } & \multicolumn{2}{|c|}{ Ton/ fed } & \multicolumn{2}{|c|}{ Uptake (Kg/ fed) } & \multicolumn{3}{|c|}{ Uptake (g/ fed) } \\
\hline (TSP) Triple superphosphate & 8.394 & 111.13 & $11.35^{\star}$ & 183.59 & 3085.50 & 800.53 & $307.74^{\star}$ \\
\hline (SSP)single superphosphate & $8.483^{\star}$ & 113.07 & 10.09 & 179.58 & 3268.94 & 854.31 & 253.31 \\
\hline LSD at 5\% & & $\mathrm{NS}$ & & $\mathrm{NS}$ & $\mathrm{NS}$ & $\mathrm{NS}$ & \\
\hline Ammonium Salphate & 8.782 & 125.5 & 11.36 & 168.5 & 3586 & 877.4 & 314.8 \\
\hline Calcium Nitrate & 8.237 & 106.7 & 10.31 & 186.7 & 3075 & 823.1 & 275.5 \\
\hline Urea & 8.297 & 104.2 & 10.48 & 189.6 & 2870 & 781.8 & 251.3 \\
\hline LSD at 5\% & 0.218 & 10.55 & 0.50 & 12.50 & 118.7 & 85.81 & 15.06 \\
\hline (TSP) Ammonium Salphate & 8.832 & 127.8 & 11.91 & 169.7 & 3230 & 843.4 & 353.0 \\
\hline (TSP)+ Calcium Nitrate & 7.988 & 102.9 & 10.78 & 183.6 & 3038 & 854.3 & 305.6 \\
\hline (TSP) + Urea & 8.363 & 102.7 & 11.35 & 197.4 & 2988 & 703.9 & 264.5 \\
\hline (SSP) + Ammonium & 8.732 & 123.1 & 10.80 & 167.2 & 3943 & 911.3 & 276.6 \\
Salphate & & & & & & & \\
\hline (SSP) Calcium Nitrate & 8.487 & 110.5 & 9.85 & 189.8 & 3111 & 791.8 & 245.4 \\
\hline (SSP) + Urea & 8.232 & 105.6 & 9.62 & 181.7 & 2753 & 859.8 & 238.0 \\
\hline LSD at 5\% & 308.8 & 14.91 & 0.71 & 17.67 & 167.9 & 121.4 & 21.30 \\
\hline
\end{tabular}

Table (7): Effect of phosphorus and nitrogen fertilizer sources on biological yield, macro and micronutrients uptake of wheat plant grown in saline soil

\begin{tabular}{|c|c|c|c|c|c|c|c|}
\hline \multirow[t]{2}{*}{ Treatments } & $\begin{array}{l}\text { biological } \\
\text { yield }\end{array}$ & $\mathbf{N}$ & $\mathbf{P}$ & $\mathbf{k}$ & $\mathrm{Fe}$ & Zn & Mn \\
\hline & Ton/ fed & \multicolumn{3}{|c|}{ Uptake (Kg/ fed) } & \multicolumn{3}{|c|}{ Uptake (g/ fed) } \\
\hline \begin{tabular}{|l} 
(TSP) \\
superphosphate
\end{tabular} & $4.682^{*}$ & 62.91* & $5.29^{*}$ & $29.85^{\star}$ & $2410^{\star}$ & $504.83^{*}$ & 204.20* \\
\hline (SSP)single superphosphate & 3.416 & 44.85 & 3.53 & 21.77 & 1630 & 390.86 & 138.23 \\
\hline \multicolumn{8}{|l|}{ LSD at $5 \%$} \\
\hline Ammonium Salphate & 4.570 & 61.84 & 5.21 & 25.93 & 2347 & 515.6 & 208.1 \\
\hline Calcium Nitrate & 3.759 & 47.49 & 3.96 & 26.64 & 1937 & 416.0 & 150.7 \\
\hline Urea & 3.816 & 52.30 & 4.05 & 24.85 & 1775 & 411.9 & 154.9 \\
\hline LSD at $5 \%$ & NS & 8.19 & 0.81 & NS & 524.8 & 98.30 & 33.66 \\
\hline (TSP) Ammonium Salphate & 5.205 & 73.77 & 6.34 & 32.59 & 2737 & 566.3 & 243.8 \\
\hline (TSP)+ Calcium Nitrate & 4.660 & 57.43 & 4.97 & 31.65 & 2480 & 525.4 & 191.9 \\
\hline$($ TSP $)+$ Urea & 4.180 & 57.54 & 4.54 & 25.31 & 2013 & 422.8 & 177.0 \\
\hline $\begin{array}{l}\text { (SSP) } \\
\text { Salphate }\end{array}$ & 3.936 & 49.92 & 4.09 & 19.27 & 1957 & 464.8 & 172.4 \\
\hline (SSP) Calcium Nitrate & 2.859 & 37.56 & 2.93 & 21.64 & 1395 & 306.7 & 109.5 \\
\hline$($ SSP) + Urea & 3.452 & 47.06 & 3.57 & 24.39 & 1538 & 401.1 & 132.8 \\
\hline LSD at $5 \%$ & 1.206 & 11.58 & 1.14 & 9.75 & 742.2 & 139.0 & 47.61 \\
\hline
\end{tabular}

\section{3-Protein percentage in grains}

Data presented in Tables (2 and 3 ) showed that there was insignificant differences between phosphorus sources on protein percentage in wheat grains grown in both soils. Meanwhile, results revealed that the ammonium sulphate gave the highest significant protein percentage in two locations compared to the other treatments. Regarding the effect of interaction between the studied factors, the ammonium sulphate + triple superphosphate achieved the highest significant protein $\%$ in both soils 
compared with the other treatments. Similar finding was obtained by Taalab and Badr (2007)

\section{REFERENCES}

Abdelfattah, M. A., Sh. A. Shahid and Y. R. Othman (2009). Soil salinity mapping model developed using RS and GIS-A case study from Abu Dhabi, United Arab Emirates. Eur. J. Sci. Res., 26: 342-351.

Aboushal, A. A. and A. EL-Ashtar (2006). Response of wheat to nitrogen fertilization under saline irrigation water conditions. J. Adv. Agric. Res. 11(1):143-155.

Bermstein, L., L. E. Francois, and R. A. Clark (1974). Interactive effects of salinity and fertility on yields of grains and vegetables. Agron. J., 66:412421.

Black, C. A. (1982). Methods of Soil Analysis. Part 2. Chemical and Microbiological Properties. Second Edition. Amer. Soc. of Agron. Madison, Wisconsin, U.S. A.

El- Dewiny, Camilia Y., H. A. El-Aila and Saffe A. Mohamed (2005). Evaluation of sorghum response to different sources and rates of phosphorus fertilizers. Egypt. J. Soil Sci., 45:31-40.

El-Etreiby, F. (2002). Effect of high saline irrigation waters on some soil properties and wheat cultivars. Alex. Sci. Res., 23: 77-91.

El- Sherief, M. A. B., A. A. Rahmou and E. A. Abd el-latif (2008). Effect of various sources and rates of $\mathrm{N}$ - fertilizers on its accumulation in both soil and maize in North Sinai. Minufiya J. Agric. Res., 33: 1205-1219.

Epstein, E. (1985). Salt tolerance of crops: origin, development, and prospects of the concept. Plant and Soil. 89:187-198.

Epstein, E. and D. W. Rains (1987). Advances in salt tolerance. Plant and Soil. 99:17-29.

Fawzy, S.I., M.A. Farah; N. A. Mohamed and N.A. Barakat (1977). The of salinity and $\mathrm{N}$ level interaction effect on yield of different wheat varieties. Agric. Res. Rev., 59:129-141.

François, L. E., E. V. Mass, T. J. Donvan, and V. L. Youngs (1986). Effect of salinity on grain yield and quality, vegetative growth, and germination of semi- dwarf and durum wheat. Agron. J., 78:1053-1058.

Gahoonia, T. S., N. Claassen and A. Jungk (1992). Mobilization of phosphate in different soils by ryegrass supplied with ammonium or nitrate. Plant and Soil. 140: 241-248.

Irshad, M.; T.Honna ; A. E. Eneji and S.Yamamoto (2002).Wheat response to nitrogen source under saline conditions . Journal of plant nutrition. 25: 2603-2612.

Jungk, A., B. Seeling and J. Gerke (1993). Mobilization of different phosphate fractions in the rhizosphere. Plant and Soil. 155/156:91-94.

Mitchell, R. L. (1964). Trace elements in soils in F. E. Bear ed "Chemistry of the soil" Reinhold Pub. Crop. NY. USA

Rayan, J., S. Garabet, K. Harmsen and A. Rashid (1996). A Soil and Plant Analysis Manual Adapted For The West Asia and North Africa Region. ICARDA, Aleppo, Syria. 140pp.

Schenk, M. k. and S. A. Barber (1979). Root characteristics of corn genotypes as related to $P$ uptake. Agron. J., 71:921-925.

Snedecor, G. W. and W. G. Cochran (1980). One way classification-Analysis of Variance - The random effect model- Two way Classification (Eds) In Statistical Methods. The lowa State Univ. Press Ames lowa, USA, 215273. 
Soliman M.S., A.M. Daoud and N. Sh. Nashed (2004). The effects of fertilization regime and salt stress on yield and antioxidants in wheat (Triticum aestivum L.).Minufiya J. Agric. Res., 29: 1045- 1057.

Soliman, M.S. and M. Doss (1992). Salinity and mineral nutrition effects on growth and accumulation of organic and inorganic ions in two cultivated tomato varieties. J. Plant Nutr., 15: $2789-2799$.

Taalab, A.S. and M. A. Badr (2007). Phosphorus Availability from Compacted Rock Phosphate with Nitrogen to Sorghum Inoculated with Phosphobacterium. J. Appl. Sci. Res., 3 (3): 195-201.

Waller, R. A. and C. B. Duncan (1969). Abays rule for symmetric multiple comparison problem Amer. State Assoc. Jour. December: 1485-1503.

Youssef, R.A. and M. Chino (1988). Development of a new rhizopox system to study the nutrient status in the rhiizosphere. Soil Sci. Plant Nutr., 34: 461467.

Zhang, F. S.,Kang J, Kang, R. Zhang and F. Li. (2004). Effect of nitrogen fertilization on uptake of soil inorganic phosphorus fractions in the wheat root zone. Soil Sci. Soc. Amer. J., 68: 1890-1895.

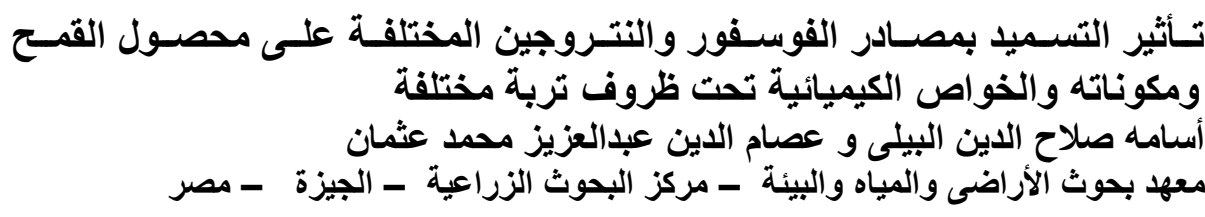

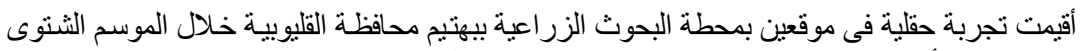

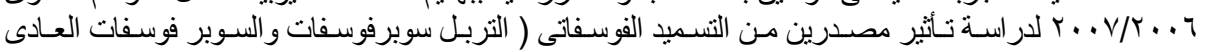

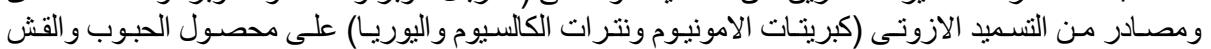

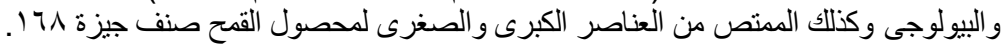
ويمكن تلخيص النتائج على النحو التالي :

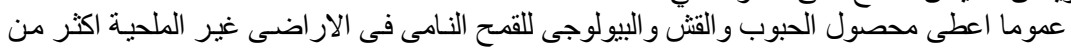

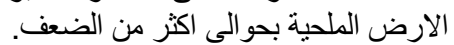

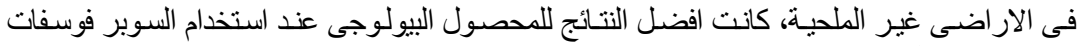

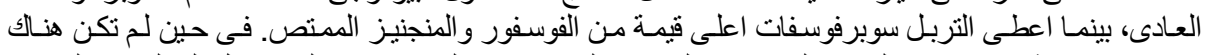

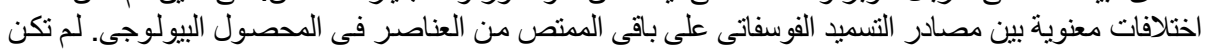

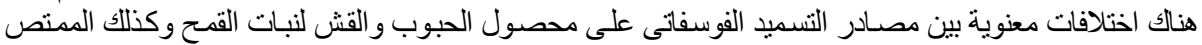

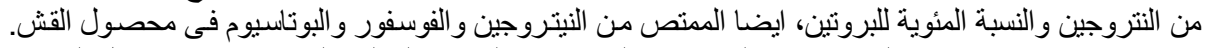

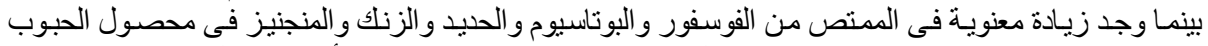

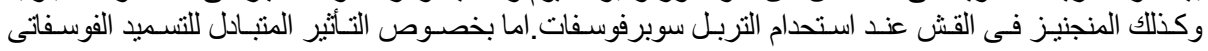

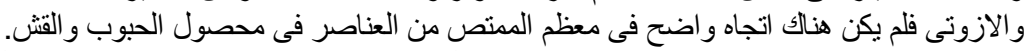

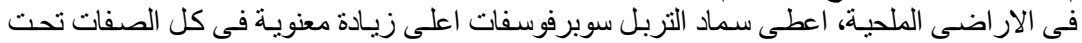

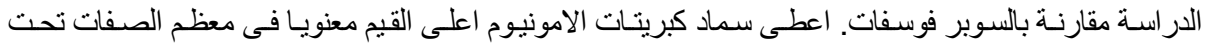

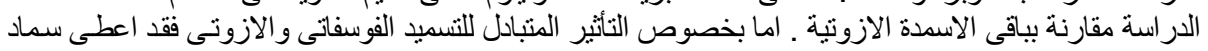

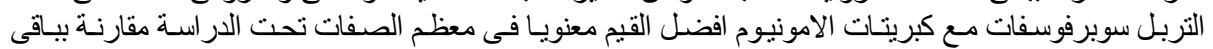

